\title{
Multimedia Environmental Fate and Transport Model of dichlorodiphenyltrichloroethane (DDT): Case Study Sayong River Watershed, Johor, Malaysia \\ (Penentuan Persekitaran Multimedia dan Model Pengangkutan Diklorodifeniltrikloroetana (DDT): Kajian Kes Tadahan Air Sungai Sayong, Johor, Malaysia)
}

\author{
Z.A. GHANI*, A.N. ANUAR, Z.A. MAJID \& M. YONEDA
}

\begin{abstract}
This study describes the development of a multimedia environmental fate and transportmodel of dichlorodiphenyltrichloroethane (DDT) at Sungai Sayong watershed. Based on the latest estimated DDT emission, the DDT concentrations in air, soil, water and sediment as well as the transfer processes were simulated under the equilibrium and steady-state assumption. Model predictions suggested that soil and sediment was the dominant sink of DDT. The results showed that the model predicted was generally good agreement with field data. Compared with degradation reaction, advection outflow was more important processes occurred in the model. Sensitivities of the model estimates to input parameters were tested. The result showed that vapour pressure (PS) and organic carbon water partition coefficient (KOC) were the most influential parameters for the model output. The model output-concentrations of DDT in multimedia environment is very important as it can be used in future for human exposure and risk assessment of organochlorine pesticides (OCPS) at Sungai Sayong Basin.
\end{abstract}

Keywords : Dichlorodiphenyltrichloroethane (DDT); modeled concentration; multimedia environmental fate and transport model; transfer processes

\section{ABSTRAK}

Penyelidikan ini membincangkan pembangunan penentuan persekitaran multimedia dan model pengangkutan diklorodifeniltrikloroetana (DDT) di kawasan tadahan air Sungai Sayong. Berdasarkan anggaran terbaru pelepasan DDT, kepekatan DDT dalam udara, tanah, air dan sedimen termasuk proses pemindahan telah disimulasi menggunakan andaian keseimbangan dan keadaan mantap. Model ramalan menyarankan tanah dan sedimen merupakan dominan semula jadi DDT. Keputusan menunjukkan model ramalan adalah sama dengan data lapangan. Berbanding tindak balas degradasi, aliran keluar perolakan haba adalah proses terpenting di dalam model ini. Kepekaan model anggaran dengan parameter input telah diuji. Keputusan menunjukkan tekanan wap air (Ps) dan pekali pembahagi karbon organik - air (KOC) adalah parameter paling berpengaruh dalam output model. Output kepekatan model DDT dalam persekitaran multimedia adalah sangat penting kerana ia dapat digunakan pada masa hadapan untuk pendedahan kepada manusia dan penilaian risiko racun serangga organoklorin (OCP) di lembangan Sungai Sayong.

Kata kunci: Diklorodifeniltrikloroetana (DDT); kepekatan model; pembangunan penentuan persekitaran multimedia dan model pengangkutan; proses pemindahan

\section{INTRODUCTION}

Over the past, environmental deterioration and natural resource destruction occurred caused by agricultural and industrial development (Sultana et al. 2014). In chemical management and environmental decision-making, it is very important to assess the regional ecological and human health risk of chemicals released into the environment (Liu et al. 2014). For this purpose sampling analysis methods are always used by researcher, but unfortunately it cannot practically capture the dynamic behavior of contaminants because these methods are costly, time-consuming and laborious and it is not practical for real-time prediction emergent events that might pose risks (Wang et al. 2012). Thus, a new tool called multimedia environmental modeling (MEM) has been introduced to predict the level distribution of a contaminant in all connected environmental (Luo et al. 2007). Therefore, in Decision Support System (DSS) for chemical risk assessment, this type model can be applied which becoming urgent need for management of Persistent Organic Pollutants (POPS) in Malaysia. The most important thing, this study is providing a useful tool for chemical risk assessment especially on a watershed scale in Malaysia in future.

As one of the agricultural country, pesticides are widely used in Malaysia. In prevention of harmful effects caused by pests, pesticide which constitutes a diverse class of chemicals extensively used and it is accumulated in soil (Ene Antoaneta \& Sion Alina 2012). Among the large numbers of pesticides, Organochlorine Pesticides (OCPs) included as an ubiquitous Persistent Organic Pollutants 
(POPs) and have been a major environmental issue, drawing extensive attention from environmental scientist and public (Kim et al. 2015). Some Organochlorine Pesticides (OCPs) such as dichlorodiphenyltrichloroethane (DDT), dieldrin and hexachlorocyclohexanes $(\mathrm{HCH})$ have been withdrawn or banned in many countries for environmental reasons and public health (Mahugija et al. 2014). Because of good effect in controlling insects and low cost, a number of Organochlorine Pesticides (OCPs) are still in use in South Asian Countries even though prohibitions on its uses have been implemented in developing nations (Usman et al. 2014). Because the ability of Organochlorine Pesticides (OCPs) can be accumulated mainly in animal tissue and enter the food chain, thus Organochlorine Pesticides (OCPs) are considered toxic substance (Luzardo et al. 2012). Their occurrence in remote areas is attributed to transport of chemicals from places where they are still in use because Organochlorine Pesticides (OCPs) are characterized by long range atmospheric transport potential (Usman et al. 2014). Thus, Organochlorine Pesticides (OCPs) were found widespread in the environmental media, such as soil, water, suspended particulate matter (SPM), sediment, atmosphere and organisms (Yu et al. 2014).

Among many types of multimedia environmental models (MEM), multimedia fugacity model has been widely used to describe the environmental behaviour of organic pollutants in local environment, regional and global environments (Xiangzhen et al. 2014). The concept of fugacity and mass balance principle are used to describe the partitioning processes in different environmental compartments and predict the concentration level, distribution and persistence of the chemicals (Liu et al. 2014).

Sungai Sayong is one of the most important river in Malaysia because it was a water sources for South
Malaysia and Singapore. The objective of this study was to develop a multimedia environmental fate and transport model to estimate the environmental distribution and transfer fluxes of dichlorodiphenyltrichloroethane (DDT) in air, soil, water and sediment at Sungai Sayong watershed. Monitoring study was conducted on December 2014 and February 2015. The measured distributions of dichlorodiphenyltrichloroethane (DDT) were compared with the modeled concentration results using log difference for model validation. The model was also assessed by using sensitivity analysis to determine the most influential parameters for the model. The results from this study were expected to be useful for local government agencies to manage dichlorodiphenyltrichloroethane (DDT) at the watershed.

\section{METHODS}

\section{STUDY AREA AND SEGMENTATION}

Sungai Sayong is one of the 12 tributaries in Sungai Johor Basin. Sungai Sayong has a watershed area of about $480238 \mathrm{~km}^{2}$. There are 12 tributaries in Sungai Sayong watershed. In order to distinguish different types of study areas, Sungai Sayong watershed was divided into 3 sections: upstream, midstream and downstream using Geographical Information System (GIS) analysis. In general, the economic activities in the 3 sections are same, with mainly palm oil plantation activities. Sungai Sayong Basin is important to be managed effectively because it is the source of water intake in Johor. Monitoring activities were carried out on December 2014 and January 2015 to provide the DDT data in air, soil, water and sediment at Sungai Sayong watershed. Study area and sampling stations were presented in Figure 1. This data was used in model validation.

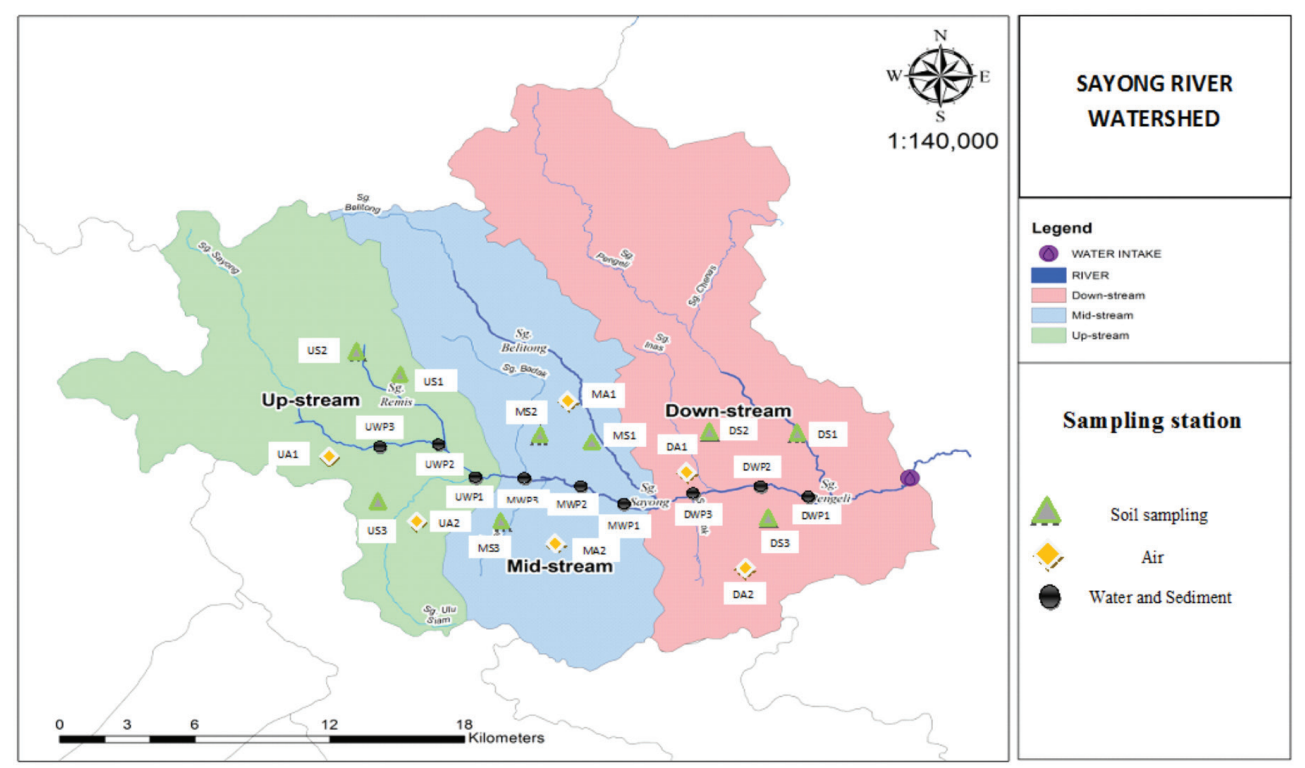

FIGURE 1. Sampling stations 


\section{MODEL FRAMEWORK}

Based on approach of Mackay (2001), a fugacity model was developed to describe the distribution, degradation reaction and advection loss processes of DDT at Sungai Sayong Basin as well as its different sections. The processes and compartments taken into consideration are defined in Figure 2. As the steady state fugacity model assumed, each section in this river basin is completely mixed. For each section, an equilibrium and steady state model treats four compartments: air, soil, water and sediment. Steady-state equation is written in fugacity format to simplify them. Fugacity (f, Pa) is a criterion of equilibrium of chemical partition between phases, which is related to the concentration $\left(\mathrm{C}, \mathrm{mol} / \mathrm{m}^{3}\right)$ by the expression,

$$
\mathrm{C}_{\mathrm{i}}=\mathrm{Z}_{\mathrm{i}} f
$$

where $\mathrm{Z}_{\mathrm{i}}\left(\mathrm{mol} / \mathrm{m}^{3} . \mathrm{K}\right)$ is the fugacity capacity of chemical in compartment. The function of $\mathrm{Z}$ value depends on the physical and chemical properties of the chemical and various characteristics of each compartment. Table 1 shows the fugacity capacity formulation of each compartment.

Whereas, $f_{i}$ is fugacity $(\mathrm{Pa})$ in compartment $\mathrm{i}$. Fugacity $(f, \mathrm{~Pa})$ represents the tendency of the fluid to escape or expand isothermally and has units pressure (Mackay 2001). For level II fugacity model, there is no active transport between environmental media. This assumption means that a single fugacity exists in the environment (2). Therefore, the fugacity of a chemical in a homogenous compartment as shown in (2);

$$
f_{\text {AIR }}=f_{\text {SOIL }}=f_{\text {WATER }}=f_{\text {SEDIMENT }}=f_{\mathrm{i}}=f
$$

Fugacity, $f$ can be derived as;

$$
f=\sum \mathrm{C}_{\mathrm{i}} \mathrm{V}_{\mathrm{i}} / \sum \mathrm{V}_{\mathrm{i}} \mathrm{Z}_{\mathrm{i}}
$$

Thus, fugacity, $f$;

$$
f=\mathrm{M} / \Sigma \mathrm{VZ}
$$

where $f$ is fugacity $(\mathrm{Pa})$; $\mathrm{M}$ is total amount of chemical (mol); $\mathrm{V}$ is volume $\left(\mathrm{m}^{3}\right)$ of a compartment; and $\mathrm{Z}$ is fugacity capacity $\left(\mathrm{mol} / \mathrm{m}^{3} . \mathrm{Pa}\right)$ of chemical in a compartment.

TABLE 1 . Fugacity capacity ( $\mathrm{Z}$ value) formulation of each compartment

\begin{tabular}{ccc}
\hline Compartment & Symbol & Fugacity capacity \\
\hline Air & $\mathrm{Z}_{\text {AIR }}$ & $1 / \mathrm{RT}$ \\
Soil & $\mathrm{Z}_{\text {SOIL }}$ & $\phi \mathrm{OC}_{\text {SOIL }} \times \mathrm{Z}_{\text {WATER }} \times \rho_{\text {SOIL }} \times \mathrm{K}_{\mathrm{OC}} / 1000$ \\
Water & $\mathrm{Z}_{\text {WATER }}$ & $1 / \mathrm{H}$ \\
Sediment & $\mathrm{Z}_{\text {SEDIMENT }}$ & $\phi \mathrm{OC}_{\text {SEDIMENT }} \times \mathrm{Z}_{\text {WATER }} \times \rho_{\text {SEDIMENT }} \times \mathrm{K}_{\mathrm{OC}} / 1000$ \\
& &
\end{tabular}

where $\mathrm{R}$ is the gas constant $\left(8.13 \mathrm{~Pa}-\mathrm{m}^{3} \mathrm{~mol}^{-1} \mathrm{~K}^{-1}\right)$; $\mathrm{T}$ is the ambient temperature $(\mathrm{K}) ; \mathrm{H}$ is the Henry's law constant $\left(\mathrm{Pa}-\mathrm{m}^{3} / \mathrm{mol}\right) ; \Phi \mathrm{OC}_{\mathrm{i}}$ is the organic carbon content in compartment i (-); $\rho_{i}$ is the density of compartment $i(\mathrm{~kg}$ $\left.\mathrm{m}^{-3}\right) ; \mathrm{K}_{\mathrm{OC}}$ is the organic carbon - water partition coefficient of chemical; and $\mathrm{Z}_{\mathrm{i}}$ is the fugacity capacity of compartment $\mathrm{i}\left(\mathrm{mol} / \mathrm{m}^{3} \cdot \mathrm{Pa}\right)$.

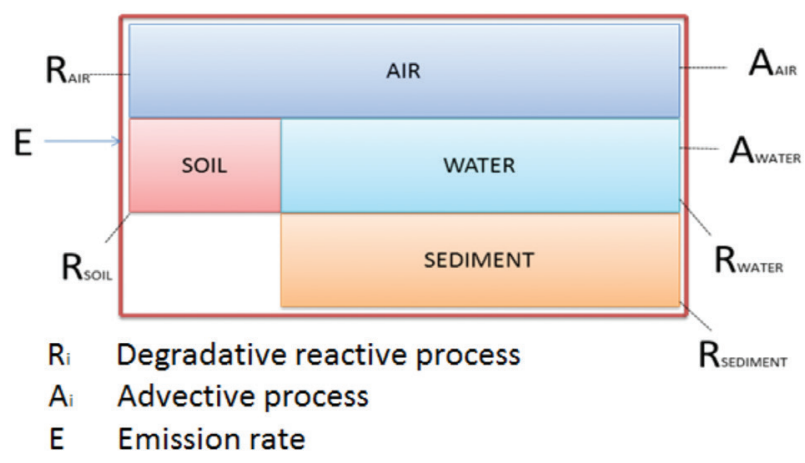

FIGURE 2. Compartments and processes

Besides, the transfer fluxes that describe the chemical movement in each compartment can be calculated based on transfer coefficient (D, mol/h.Pa) and fugacity based on Mackay (2001). Under a steady state assumption, the process taken into consideration included advective air and water flow and degradation in air, soil, water and sediment. These transfer processes and corresponding D value are summarized in Table 2.

The general mass balance equation was established in term of transfer fluxes in each phase.

$$
\mathrm{I}=\mathrm{E}+\Sigma \mathrm{D}_{\mathrm{Ai}}+\Sigma \mathrm{D}_{\mathrm{Ri}}
$$

where I is total flux; $\mathrm{E}$ is total emission rate; $\mathrm{D}_{\mathrm{Ai}}$ is advective fugacity rate constant in compartment $\mathrm{i}$; and $\mathrm{D}_{\mathrm{Ri}}$ is the degradation fugacity rate constant in compartment $\mathrm{i}$.

TABLE 2. Transfer processes and D value

\begin{tabular}{lll}
\hline Symbol & Transfer process & Related D value \\
\hline $\mathrm{A}_{\text {AIR }}$ & Advection in air & $(\mathrm{V} / \mathrm{t})_{\text {AIR }} \mathrm{Z}_{\text {AIR }}$ \\
$\mathrm{R}_{\text {AIR }}$ & Degradation in air & $\mathrm{V}_{\text {AIR }} \mathrm{Z}_{\text {AIR }} \mathrm{k}_{\text {AIR }}$ \\
$\mathrm{R}_{\text {SOIL }}$ & Degradation in soil & $\mathrm{V}_{\text {SOIL }} \mathrm{Z}_{\text {SOIL }} \mathrm{k}_{\text {SOIL }}$ \\
$\mathrm{A}_{\text {WATER }}$ & Advection in water & $(\mathrm{V} / \mathrm{t})_{\text {WATER }} \mathrm{Z}_{\text {WATER }}$ \\
$\mathrm{R}_{\text {WATER }}$ & Degradation in water & $\mathrm{V}_{\text {WATER }} \mathrm{Z}_{\text {WATER }} \mathrm{k}_{\text {WATER }}$ \\
$\mathrm{R}_{\text {SEDIMENT }}$ & Degradation in sediment & $\mathrm{V}_{\text {SEDIMENT }} \mathrm{Z}_{\text {SEDIMENT }} \mathrm{k}_{\text {SEDIMENT }}$ \\
\hline
\end{tabular}

$\mathrm{V}_{i}$ is the volume of compartment $\left(\mathrm{m}^{3}\right) ; \mathrm{t}_{i}$ is the residence time $(\mathrm{h}) ; \mathrm{Z}_{i}$ is the fugacity capacity of chemical in compartment $\left(\mathrm{mol} / \mathrm{m}^{3} . \mathrm{Pa}\right)$; and $\mathrm{k}_{i}$ is the compartment's reaction half- life $(\mathrm{h})$ 


\section{MODEL CALCULATION}

After the collection of related parameters of the DDT and watershed were achieved, the concentration and transfer processes of DDT in air, soil, water and sediment at Sungai Sayong watershed were calculated and coded using MSEXCEL Visual Basic Application (VBA). Then the calculated results were compared with measured results for validation.

\section{INPUT PARAMETERS}

Parameters including physical-chemical properties of DDT, environmental parameters and emission rate were collected for the model. The physical-chemical properties of DDT derived from Mackay et al. (2006) were used as input of this model as presented in Table 3. Environmental parameters used in this model such as compartment properties and organic carbon contents. Compartment properties such as compartment area and height obtained from landused map as spatial analysis using GIS software. Table 4 shows the area of land used type of each section. The area of compartment was estimated from latest land used map which provided by the Johor Government Databases. The area of air was assumed as the total area of each section, whereas the area of sediment was followed exactly the area of surface water. While the height of each compartment based on several literature and study site value was listed in Table 5. Other compartment properties listed in Table 6. DDT concentration was based on average concentration of DDT of each section from the Department of Agriculture, Johor. Concentration was then conversed into total emission by multiplying with landused of palm oil and agriculture of each section and volume of spraying per square meter $\left(0.001 \mathrm{~L} / \mathrm{m}^{2}\right)$. Once a week result was applied as spraying frequency. Table 7 shows estimated DDT emission rate were obtained from the Department of Agricultural and site-survey.

\section{SENSITIVITY ANALYSIS}

A good overview of the most sensitive components of the model can be determined through sensitivity analysis. This analysis provides a measure of the sensitivity of

TABLE 3. Physical-chemical properties of DDT

\begin{tabular}{lccc}
\hline Properties & Symbol & Unit & Value \\
\hline Molar mass & $\mathrm{M}$ & $\mathrm{g} / \mathrm{mol}$ & 354.49 \\
Gas constant & $\mathrm{R}$ & $\mathrm{Pa} \cdot \mathrm{m}^{3} / \mathrm{mol} . \mathrm{K}$ & 8.314 \\
Temperature & $\mathrm{T}$ & $\mathrm{K}$ & 298 \\
Vapour pressure & $\mathrm{P}_{\mathrm{S}}$ & $\mathrm{Pa} \cdot \mathrm{m}^{3} / \mathrm{mol} . \mathrm{K}$ & 0.00002 \\
Water solubility & $\mathrm{C}_{\mathrm{S}}$ & $\mathrm{mol} / \mathrm{m}^{3}$ & 0.00012 \\
Water solubility & & $\mathrm{g} / \mathrm{m}^{3}$ & 0.0055 \\
Henry Law Constant & $\mathrm{H}$ & $\mathrm{Pa} \cdot \mathrm{m}^{3} / \mathrm{mol}^{3} \mathrm{~K}$ & 0.166666667 \\
Organic carbon - water partition coefficient & $\mathrm{K}_{\mathrm{OC}}$ & - & 635014.8138 \\
Log octanol-water partition coefficient & $\mathrm{LOGK}_{\mathrm{OW}}$ & - & 6.19 \\
Octanol-water partition coefficient & $\mathrm{K}_{\mathrm{OW}}$ & - & 1548816.619 \\
Reaction half-life in Air & $\mathrm{t}_{1 / 2}$ & $\mathrm{Hour}$ & 170 \\
Reaction half-life Soil & $\mathrm{t}_{1 / 2}$ & Hour & 17000 \\
Reaction half-life Water & $\mathrm{t}_{1 / 2}$ & Hour & 5500 \\
Reaction half-life Sediment & $\mathrm{t}_{1 / 2}$ & Hour & 55000 \\
\hline
\end{tabular}

TABLE 4. Landused of Sungai Sayong watershed $\left(\mathrm{m}^{2}\right)$

\begin{tabular}{lccc}
\hline & Upstream & Midstream & Downstream \\
\hline Total area & 2060.14 & 17753.1 & 28202.68 \\
Water & 124.18 & 94.93 & 71.11 \\
Transportation & 205.64 & 76.77 & 144.73 \\
Orchad & 314.57 & 205.6 & 0 \\
Palm oil & 14535.79 & 1559.9 & 27562.29 \\
Urban area & 131.87 & 306.72 & 1003.25 \\
Grooves & 58.52 & 0 & 196.36 \\
Mangroves & 106.43 & 0.1 & 52.73 \\
Vacant land & 267.16 & 15.62 & 0 \\
Rubber & 47.68 & 0 & 284.59 \\
Forest & 3010.75 & 33.38 & 610.63 \\
Agriculture & 142.08 & 0 & 0 \\
\hline
\end{tabular}


TABLE 5. Compartment height assumption (m)

\begin{tabular}{ccccc}
\hline Compartment & Upstream & Midstream & Downstream & Reference \\
\hline Air & 700 & 700 & 700 & Luo et al. 2007 \\
Soil & 0.2 & 0.2 & 0.2 & Luo et al. 2007 \\
Water & 4 & 4 & 3 & Site measurement \\
Sediment & 0.05 & 0.05 & 0.05 & Luo et al. 2007 \\
\hline
\end{tabular}

TABLE 6. Compartment properties

\begin{tabular}{lcccccl}
\hline & Symbol & Unit & Upstream & Midstream & Downstream & Reference \\
\hline Organic carbon content in soil & oc $_{\text {SOIL }}$ & - & 0.029 & 0.029 & 0.029 & Coulibaly et al. 2004 \\
Organic carbon content in sediment & Ooc $_{\text {SEDIMENT }}$ & - & 0.025 & 0.025 & 0.025 & Coulibaly et al. 2004 \\
Advective residence time for air & $\mathrm{T}_{\text {AIR }}$ & $\mathrm{H}$ & 1 & 1 & 1 & Mackay 2001 \\
Advective residence time for water & $\mathrm{T}_{\text {WATER }}$ & $\mathrm{H}$ & 240 & 240 & 240 & Mackay 2001 \\
Density of soil & $\rho_{\text {SOIL }}$ & $\mathrm{kg} / \mathrm{m}^{3}$ & 2400 & 2400 & 2400 & Luo et al. 2007 \\
Density of sediment & $\rho_{\text {SOIL }}$ & $\mathrm{kg} / \mathrm{m}^{3}$ & 2000 & 2000 & 2000 & Luo et al. 2007 \\
\hline
\end{tabular}

TABLE 7. Estimated DDT emission

\begin{tabular}{cc}
\hline Section & Emission rate \\
\hline Upstream & 0.5642 \\
Midstream & 0.2257 \\
Downstream & 0.1269 \\
\hline
\end{tabular}

parameters, forcing functions or sub-models to the state variables of greatest interest in the model. In practical modeling, the sensitivity analysis is carried out by changing the parameters, forcing functions and sub-models, and the corresponding response of the selected state variables is observed (Jorgensen 1994). In this study, the sensitivity analysis was performed only for the parameters. A change for the parameter at $\pm 10 \%$ was chosen and the sensitivity coefficient (S) was calculated by the following formula (Coulibaly et al. 2004):

$$
\mathrm{S}=\left(\mathrm{Y}_{1.1}-\mathrm{Y}_{0.9}\right) /(0.2 \times \mathrm{Y})
$$

The terms, $\mathrm{Y}_{1.1}$ and $\mathrm{Y}_{0.9}$, represent the estimated concentrations when the tested parameter was changed at $+10 \%$ and $-10 \%$, respectively. The greater the absolute value of sensitivity coefficient, the more sensitive the parameter (Coulibaly et al. 2004).

\section{RESULTS AND DISCUSSION}

\section{MODELED CONCENTRATION OF DDT}

Modeled concentration of DDT in air, soil, water and sediment at upstream, midstream and downstream areas of Sungai Sayong Watershed were obtained from modeled calculation carried out under the steady state, equilibrium and homogeneous assumptions. The calculation based on fugacity approach. The calculated DDT concentration in air, soil, water and sediment are presented in Figure 3.
Based on the modeled results, DDT mostly found in soil compartment followed by sediment. At upstream area, soil has the highest concentration of DDT with $1.506 \times 10^{-5}$ $\mathrm{mol} / \mathrm{m}^{3}$ followed by sediment with $1.082 \times 10^{-5} \mathrm{~mol} / \mathrm{m} 3$ and water $3.408 \times 10^{-10} \mathrm{~mol} / \mathrm{m}^{3}$ and least in air with 1.770 $\times 10^{-13} \mathrm{~mol} / \mathrm{m}^{3}$ as can be seen in Figure 3(a). Next, Figure 3 (b) shows that in midstream, DDT mostly found in soil $\left(1.213 \times 10^{-4} \mathrm{~mol} / \mathrm{m}^{3}\right)$ followed by sediment $\left(8.716 \times 10^{-5}\right.$ $\left.\mathrm{mol} / \mathrm{m}^{3}\right)$, water $\left(2.745 \times 10^{-9} \mathrm{~mol} / \mathrm{m}^{3}\right)$ and air $\left(1.428 \times 10^{-12}\right.$ $\left.\mathrm{mol} / \mathrm{m}^{3}\right)$. Whereas for downstream area DDT mostly highest in soil $\left(1.744 \times 10^{-4} \mathrm{~mol} / \mathrm{m} 3\right)$ followed by sediment $(1.253$ $\left.\times 10^{-4} \mathrm{~mol} / \mathrm{m}^{3}\right)$, water $\left(3.946 \times 10^{-9} \mathrm{~mol} / \mathrm{m}^{3}\right)$ and air $(2.053$ $\left.\times 10^{-12} \mathrm{~mol} / \mathrm{m}^{3}\right)$ as shown in Figure 3(c).

In this study, only soil compartment was assumed to receive direct emission source of DDT. Therefore, most DDT was distributed in soil. Sediment received no direct DDT or advective input. However, the accumulation of DDT might caused by soil erosion process. Previously, the distribution of OCP which was hexachlorocyclohexana $(\mathrm{HCH})$ in water, air and sediment at Lake Chaohu, China were simulated with a developed fugacity-based. Based on the study $\mathrm{HCH}$ was found highest in sediment phase $\left(1.00 \times 10^{-4} \mathrm{~mol} / \mathrm{m}^{3}\right)$ followed by water $\left(1.05 \times 10^{-6} \mathrm{~mol} / \mathrm{m}^{3}\right)$ and air $(1.07 \times$ $10^{-11} \mathrm{~mol} / \mathrm{m}^{3}$ ) (Kong et al. 2014). Besides, the simulation on triclosan (TCS) and triclocarban (TCC) distribution in the Dongjiang River Basin, South China was conducted using fugacity concept. According to the study, same to OCPS, compound of TCS and TCC were highest in sediment $4.162 \times 10^{-5} \mathrm{~mol} / \mathrm{m}^{3}$ and $3.82 \times 10^{-4} \mathrm{~mol} / \mathrm{m}^{3}$, respectively, followed by soil $5.31 \times 10^{-11} \mathrm{~mol} / \mathrm{m}^{3}$ and $1.29 \times 10^{-14} \mathrm{~mol} /$ $\mathrm{m}^{3}$ for TCS and TCC, respectively (Zhang et al. 2013).

If compared for three sections (upstream, midstream and downstream), DDT in soil and sediment at downstream area was highest followed by midstream and upstream. This happened because the emission rate of DDT at downstream area was higher compared to midstream and upstream. In short, it can be seen from the model, concentration of DDT in soils were highest for all sections. This is because 


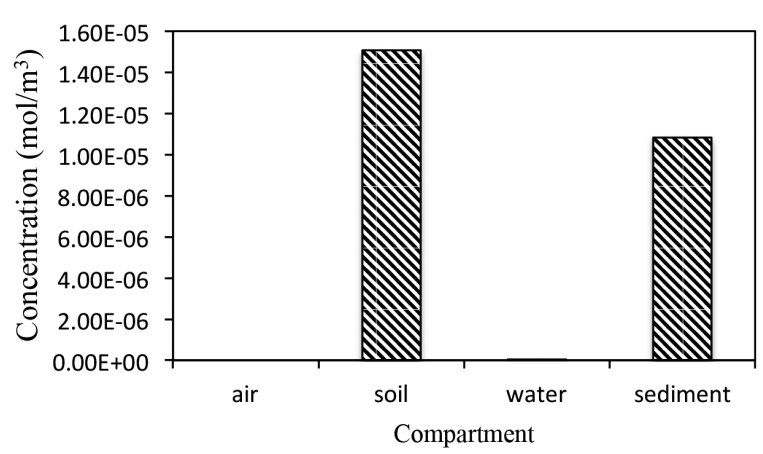

(a)

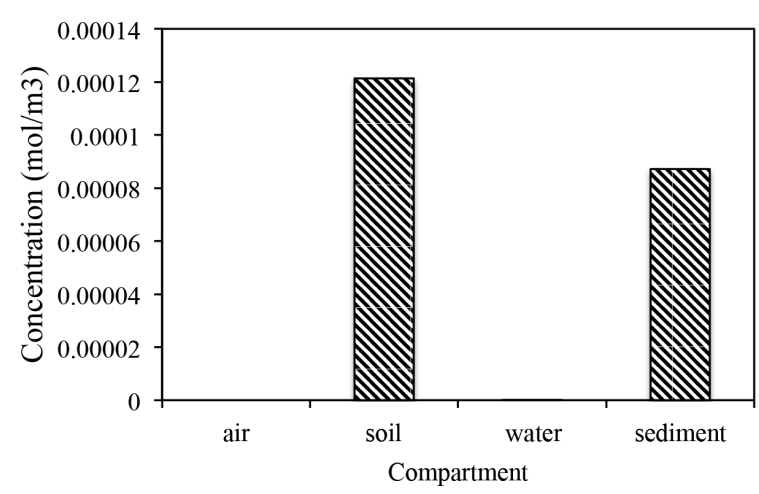

(b)

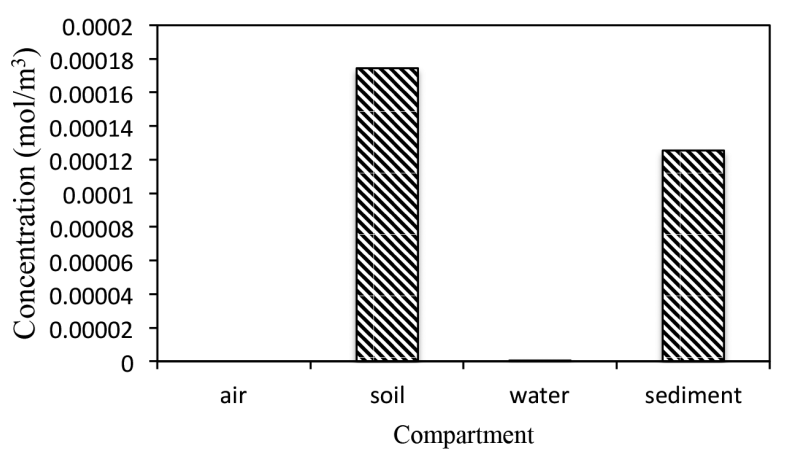

(c)

FIGURE 3. Modeled concentration of DDT at Sungai Sayong watershed for (a) upstream (b) midstream and (c) downstream

reaction half-life $\left(\mathrm{t}^{1 / 2}\right)$ of DDT in soil and sediment were higher than air and water. Thus, DDT degraded slowly and attached longer at the soil and sediment particles. The dissolved DDT concentration in the water was lower with the increase of their molecular weight, probably due to the decreasing solubility.

\section{COMPARISON OF DDT CONCENTRATION WITH FIELD DATA}

In this study, Gas Chromatography-mass spectrometry (GC-MS) analysis showed that there was no dichlorodiphenyltrichloroethane (DDT) detected in most air samples collected at Sungai Sayong Watershed except in midstream area. In midstream area, the mean concentration of dichlorodiphenyltrichloroethane (DDT) in air was 0.37 $\mu \mathrm{g} / \mathrm{g}$ (Figure 4) which was lower than soil and sediment. The presence of this compound in air was supported in previous study. For instance on 2011, a study of DDT was conducted to measure its distribution in atmosphere. dichlorodiphenyltrichloroethane (DDT) was also detected in air samples. For examples, dichlorodiphenyltrichloroethane (DDT) was found at metropolitan City, Turkey such as Mudanya Coastal $\left(22.5 \mathrm{pg} / \mathrm{m}^{3}\right)$, Butal Traffic (41.9 pg/ $\left.\mathrm{m}^{3}\right)$, UUC semi- rural $\left(12.5 \mathrm{pg} / \mathrm{m}^{3}\right)$ and Yavuz Selim Urban (49.5 pg/m $\mathrm{m}^{3}$ ) (Cindoruk 2011). The possible source of dichlorodiphenyltrichloroethane (DDT) in the air because of agricultural and vector elimination purposes. For instance, the usages lead to high amount of DDT detected in air at the tropical coastal atmosphere in India (Ali et al. 2014).

Next, total dichlorodiphenyltrichloroethane (DDT) concentrations in soil of the Sungai Sayong Watershed was detected in all soil samples. It can be seen from Figure 4 , DDT in soil found highest in downstream area with the mean concentration $37.8763 \mathrm{ug} / \mathrm{g}$ followed by midstream $(17.5020 \mathrm{ug} / \mathrm{g}$ ) and upstream with $0.2197 \mathrm{ug} / \mathrm{g}$. This might happened because downstream area mostly covered with palm oil agriculture with the area of $27565.29 \mathrm{~m}^{2}$ followed by midstream $15599.9 \mathrm{~m}^{2}$ and downstream $14535.79 \mathrm{~m}^{2}$. Thus, the use of DDT at downstream area might be high. Previously, the DDTs (the sum of P,P0-DDE, P,P0-DDT and $\mathrm{O}, \mathrm{P0}$-DDT + P,P0-DDD) concentration in soil samples were also detected along Chao River, China ranged from 0.1835 to $15.7150 \mathrm{ngg}^{-1}$ (Yu et al. 2014).

Besides, the total DDT concentrations in sediment of the Sungai Sayong Watershed ranged from 0.3920 to 21.3 $\mathrm{ug} / \mathrm{g}$ with a mean value of $10.0 \mathrm{ug} / \mathrm{g}$. DDT was detected in most sediment samples. It can be seen from Figure 4(c), DDT in sediment found highest in downstream area with the mean concentration $37.8763 \mathrm{ug} / \mathrm{g}$ followed by midstream $(17.5020 \mathrm{ug} / \mathrm{g})$ and upstream with $0.2197 \mathrm{ug} / \mathrm{g}$. This might happened because downstream area mostly covered with palm oil agriculture with the area of $27565.29 \mathrm{~m}^{2}$ followed by midstream $15599.9 \mathrm{~m}^{2}$ and downstream $14535.79 \mathrm{~m}^{2}$. Thus, the use of DDT at downstream area might be high.

In this study there was no DDT detected in all collected water samples. If it was present, the concentration was very low. This might happened because most organochlorine pesticides (OCPs) have an affinity for particulate matter and one of their main sinks is marine sediments (Zhou et al. 2006).

To test applicability of the developed multimedia model, modeling was performed for different sections of the Sungai Sayong Watershed: upstream, midstream, downstream. The comparative results between the modeling data and monitoring data for the DDT compound are shown in Figure 5. The modeled concentration of DDT which was calculated in $\mathrm{mol} / \mathrm{m}^{3}$ was then converted into $\mathrm{ng} / \mathrm{g}$ and ng/L. Then, both modeled and measured concentrations were converted into Log unit for comparison. As shown in the Figure 6, the modeled concentrations for DDT were comparable to and well matched with the monitoring data in all phases. 
Air

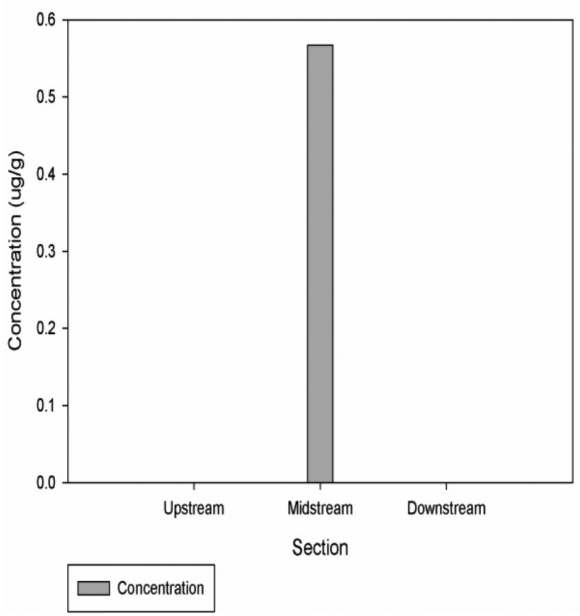

(a)
Soil

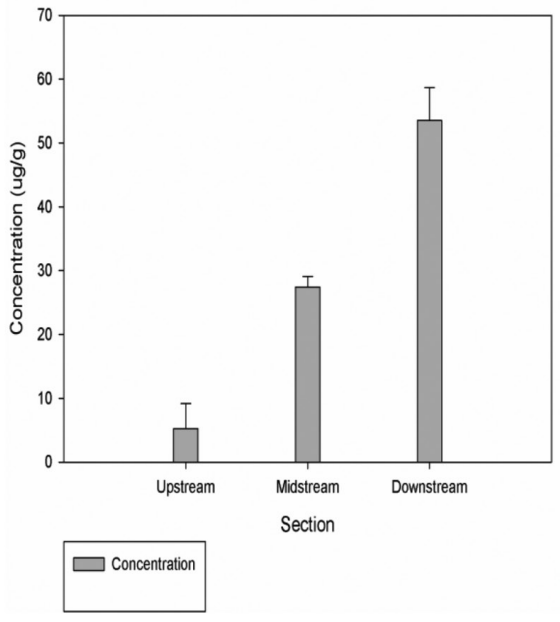

(b)

Sediment

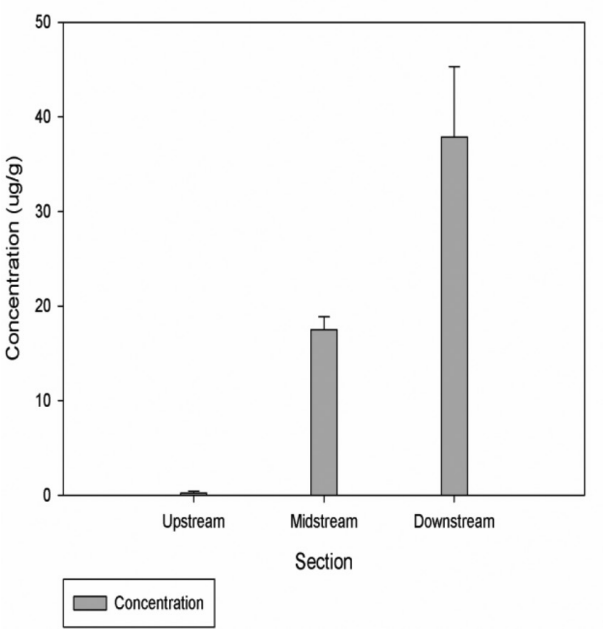

(c)

FIGURE 4. Measured concentration of DDT in (a) air (b) soil and (c) sediment

As shown in Figure 5(a) the differences between the modeled and measured means in air, soil, water and sediment phases of the upstream area were $0.00,0.01$, 0.00 and -0.06 logunits, respectively. For midstream area, the differences between the modeled and measured mean were $-0.24,0.19,0.00$ and $0.25 \log$ units for air, soil, water and sediment, respectively (Figure 5(b)). Whereas, the differences between the modeled and measured means in air, soil, water and sediment phases of the downstream area were $0.00,0.05,0.00$ and $0.02 \mathrm{log}$ units, respectively, as can be seen in Figure 5(c) (an acceptable range: 0.5-0.7 in log unit range).

For air, there were no differences between modeled and monitoring data for upstream and downstream watershed. However, large residual DDT was found in midstream area (log different: -0.24$)$. In this case the modeled result was underestimated. Since OCPs do not have point sources, they might enter the atmosphere by evaporation from previously contaminated soils, water bodies and vegetation (Cindoruk 2011). The difference occurred because in this study the model not treated those processes. For water, there were no differences between modeled and monitoring data for whole river watershed. This is the perfect matched of the modeled with $0.00 \mathrm{log}$ different. Besides, for soil the difference between modeled and monitoring data for whole watershed was 0.01-0.05 log units (in acceptable range). Measured concentrations were lower especially in downstream area.

The differences between the modeled and measured DDT concentrations for air, soil and sediment phases are attributable to the complexity of DDT source and the degree of influence by environmental changes (Xu et al. 2013). 


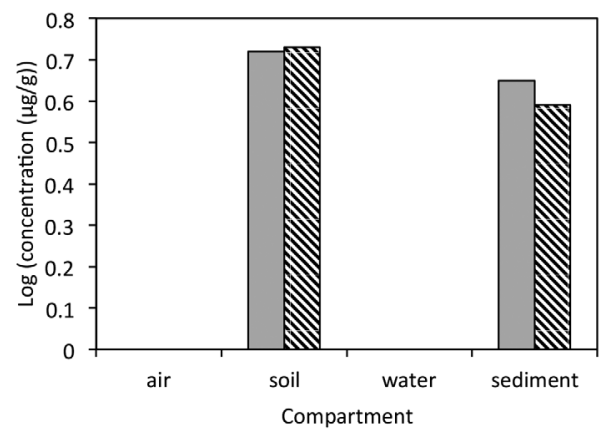

(a)

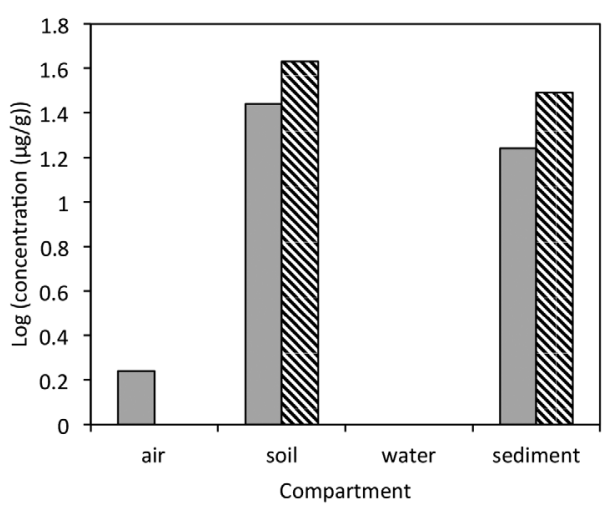

(b)

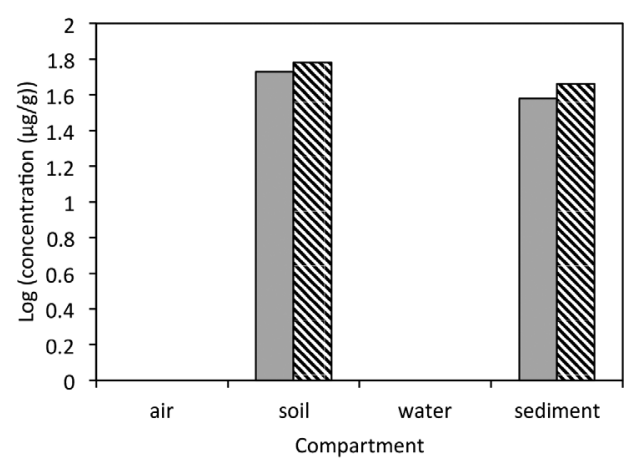

(c) $\square$ measured

వmodeled

$\square$ measured

\$ modeled

$\square$ measured

వmodeled

FIGURE 5. Comparison between measured and modeled concentration of DDT in air, soil, water and sedimant in

(a) upstream (b) midstream and (c) downstream of Sungai Sayong watershed

For all sections of the watershed, the obtained modeling values agreed well with the monitoring observations with the residual within an order of magnitude.

\section{TRANSFER PROCESSES OF DDT AT SUNGAI SAYONG WATERSHED}

To exhibit the spatial impact on the transfer processes, transfer fluxes for DDT in different sections (upstream, midstream and downstream) of the Sungai Sayong watershed are presented in this study. This model addresses the effect of advection outflow and degradation reaction on DDT fate. The fluxes into and out of the watershed area were well-balanced. Based on Table 8,

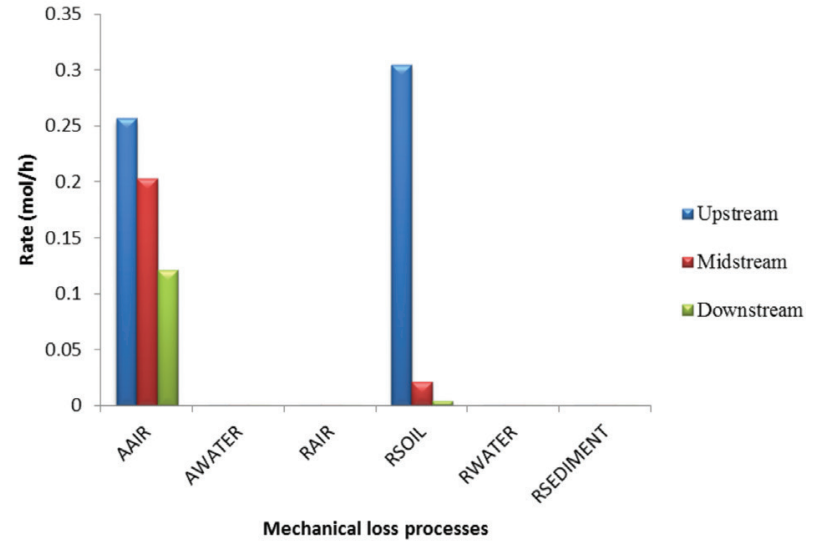

FIGURE 6. Modeled transfer processes of DDT at Sungai Sayong watershed

the relative error the total flux into and out of the upstream area was $0.0001(\mathrm{~mol} / \mathrm{h})$, for midstream $0.0019(\mathrm{~mol} / \mathrm{h})$ and downstream $0.0008(\mathrm{~mol} / \mathrm{h})$.

Transfer processes of DDT at Sungai Sayong watershed are presented in Figure 6 based on the calculated result, the loss rate process of DDT through advective air flow out of the basin area $\left(\mathrm{A}_{\mathrm{AIR}}\right)$ and degradative reactive in soil $\left(\mathrm{R}_{\text {SOIL }}\right)$ were predominant in the output of DDT. Based on figure 4-5, $\mathrm{A}_{\mathrm{AIR}}$ and $\mathrm{R}_{\text {SOIL }}$ mostly occurred in upstream area $\left(\mathrm{A}_{\text {AIR }}(0.2567 \mathrm{~mol} / \mathrm{h})\right.$ and $\left.\mathrm{R}_{\text {SOIL }}(0.3050 \mathrm{~mol} / \mathrm{h})\right)$ followed by midstream $\left(\mathrm{A}_{\mathrm{AIR}}(0.2029 \mathrm{~mol} / \mathrm{h})\right.$ and $\mathrm{D}_{\text {SOIL }}(0.0215$ $\mathrm{mol} / \mathrm{h}))$ and downstream $\left(\mathrm{A}_{\mathrm{AIR}}(0.1216 \mathrm{~mol} / \mathrm{h})\right.$ and $\mathrm{D}_{\text {SOIL }}$ $(0.0045 \mathrm{~mol} / \mathrm{h})$. Among all the loss processes, degradative reactive in water $\left(\mathrm{R}_{\text {WATER }}\right)$ was least occurred for all sections with the rate $0.00002,0.00001$ and 0.00000 for upstream, midstream and downstream, respectively.

\section{SENSITIVITIES OF MODELED CONCENTRATION TO INPUT PARAMETERS}

To compare the influence among parameters, a sensitivity coefficient (Cs) was adopted. The sensitivity coefficient higher than $0.5(>0.5)$ are considered more influential parameter in the model. The model output included the concentration of DDT in four phases including air, soil, water and sediment in three sections; upstream, midstream and downstream. The results were summarized in Table 9. Among 21 input parameters, there were only 10 parameters with sensitivity coefficients higher than 0.5. Based on Table 9, Vapour pressure (Ps) and octanolwater partition coefficient (KOC) were the most influential parameters for upstream, midstream and downstream area in the model for DDT compound.

\section{CONCLUSION}

A fugacity concept was applied to develop a multimedia environmental fate and transport model of DDT at the Sungai Sayong watershed. By using the developed model, the calculated concentrations of four DDT in various environmental media (air, soil, water and sediment) 
TABLE 8. The contribution of each transfer flux in and out of the four compartments

\begin{tabular}{|c|c|c|c|c|c|}
\hline Section & Compartment & Process in* & Coefficient rate $(\mathrm{mol} / \mathrm{h})$ & Process out* & Coefficient rate $(\mathrm{mol} / \mathrm{h})$ \\
\hline \multirow[t]{8}{*}{ Upstream } & Air & Emission & - & $\mathrm{A}_{\mathrm{AIR}}$ & 0.25670 \\
\hline & & & & $\mathrm{R}_{\mathrm{AIR}}$ & 0.00100 \\
\hline & Soil & (E) & 0.5642 & $\mathrm{R}_{\text {SOIL }}$ & 0.30502 \\
\hline & Water & & - & $\mathrm{A}_{\text {WATER }}$ & 0.00055 \\
\hline & & & & $\mathrm{R}_{\text {WATER }}^{\text {WATLK }}$ & 0.00002 \\
\hline & Sediment & & - & $\mathrm{R}_{\text {SEDIMENT }}$ & 0.00085 \\
\hline & Total $(\mathrm{mol} / \mathrm{h})$ & & 0.56242 & & 0.5641 \\
\hline & Relative error & & & 0.0001 & \\
\hline \multirow[t]{8}{*}{ Midstream } & Air & Emission & - & $\mathrm{A}_{\mathrm{AIR}}$ & 0.20285 \\
\hline & & (E) & & $\mathrm{R}_{\mathrm{AIR}}^{\mathrm{AIR}}$ & 0.00083 \\
\hline & Soil & & 0.2257 & $\mathrm{R}_{\text {SOIL }}$ & 0.02146 \\
\hline & Water & & - & $\mathrm{A}_{\text {WATER }}$ & 0.00046 \\
\hline & & & & $\mathrm{R}_{\text {WATER }}^{\text {WAIER }}$ & 0.00001 \\
\hline & Sediment & & - & $\mathrm{R}_{\text {SEDIMENT }}$ & 0.00006 \\
\hline & Total & & 0.2257 & & 0.22385 \\
\hline & Relative error & & & 0.0019 & \\
\hline \multirow[t]{8}{*}{ Downstream } & Air & & - & $\mathrm{A}_{\mathrm{AIR}}$ & 0.12159 \\
\hline & & & & $\mathrm{R}_{\mathrm{AIR}}^{\mathrm{AIK}}$ & 0.00050 \\
\hline & Soil & Emission $(\mathrm{E})$ & 0.1269 & $\mathrm{R}_{\text {SOIL }}$ & 0.00455 \\
\hline & Water & & - & $\mathrm{A}_{\text {WATER }}$ & 0.00028 \\
\hline & & & & $\mathrm{R}_{\text {WATER }}$ & 0.00000 \\
\hline & Sediment & & - & $\mathrm{R}_{\text {SEDIMENT }}$ & 0.00002 \\
\hline & Total $(\mathrm{mol} / \mathrm{h})$ & & 0.1269 & & 0.12614 \\
\hline & Relative error & & & 0.0008 & \\
\hline
\end{tabular}

TABLE 9. Sensitivity coefficients of the more sensitive parameters for the model $(\mathrm{SCi}>0.5)$

\begin{tabular}{lccccccccccccc}
\hline \multirow{2}{*}{ Upstream } & & $\mathrm{T}$ & $\mathrm{P}_{\mathrm{S}}$ & $\mathrm{C}_{\mathrm{S}}$ & $\mathrm{K}_{\mathrm{OC}}$ & $\mathrm{H}$ & $\mathrm{E}$ & $\mathrm{H}$ & $\mathrm{R}$ & $\mathrm{A}$ & $\mathrm{T}_{\text {water }}$ & $\mathrm{T}_{\text {air }}$ & $\mathrm{M}$ \\
& Air & - & -3.1 & -0.79 & -6.7 & -0.58 & -1 & -1.01 & -1.8 & -1.01 & -1.01 & -1.01 & -1.01 \\
& Soil & - & 2.6 & - & 5.6 & 1.20 & -1 & -1.01 & -1.8 & -1.01 & -1.01 & -1.01 & -1.01 \\
& Water & - & 2.6 & - & -6.7 & 1.20 & -1 & -1.01 & -1.8 & -1.01 & -1.01 & -1.01 & -1.01 \\
& Sediment & - & 2.6 & - & 5.6 & 1.20 & -1 & -1.01 & -1.8 & -1.01 & -1.01 & -1.01 & -1.01 \\
\hline \multirow{2}{*}{ Midstream } & Air & 0.9 & -1.3 & - & -1.5 & -0.64 & -1 & -1.01 & -2.45 & -1.01 & -1.01 & -1.01 & -1.01 \\
& Soil & 0.9 & 12.5 & 0.75 & 14.7 & 2.05 & -1 & -1.01 & -2.45 & -1.01 & -1.01 & -1.01 & -1.01 \\
& Water & 0.9 & 12.5 & 0.75 & -1.5 & 2.05 & -1 & -1.01 & -2.45 & -1.01 & -1.01 & -1.01 & -1.01 \\
& Sediment & 0.9 & 12.5 & 0.75 & 14.7 & 2.05 & -1 & -1.01 & -2.45 & -1.01 & -1.01 & -1.01 & -1.01 \\
\hline \multirow{2}{*}{ Downstream } & Air & 0.9 & -0.6 & - & -0.7 & -0.51 & -1 & -1.01 & -2.98 & -1.01 & -1.01 & -1.01 & -1.01 \\
& Soil & 0.9 & 16.2 & 0.89 & 17.4 & 4.32 & -1 & -1.01 & -2.98 & -1.01 & -1.01 & -1.01 & -1.01 \\
& Water & 0.9 & 16.2 & 0.89 & -0.7 & 4.32 & -1 & -1.01 & -2.98 & -1.01 & -1.01 & -1.01 & -1.01 \\
& Sediment & 0.9 & 16.2 & 0.89 & 17.4 & 4.32 & -1 & -1.01 & -2.98 & -1.01 & -1.01 & -1.01 & -1.01 \\
\hline
\end{tabular}

were obtained. The DDT was found to have a tendency to be distributed in soil and sediment for all sections (upstream, midstream and downstream). Transfer flux analysis indicates that advective air flow was the primary process for the disappearance of the chemicals in the area, followed by degradative reactive process. Besides, vapour pressure (Ps) of the chemicals and octanol-water partition coefficient (KOC) were some key influencing parameters for chemical distribution in the environment. When compared with field data, the modeled concentration of DDT was in good agreement with measured concentration. As suggestion this steady state fugacity model can be used to evaluate contamination of long range transport chemicals at the basin scale based on their usage. This tool could be adopted by various decision-makers in the management of chemicals at Sungai Sayong basin. 


\section{ACKNOWLEDGEMENTS}

A part of this research was financially supported by a Fundamental Research Grant of Universiti Teknologi Malaysia (Vote Q.J130000.2522.06H97), which is gratefully acknowledged. We also acknowledge the Department of Environmental Engineering, Kyoto University, Japan for research attachment. We acknowledge Water Research Alliance, Universiti Teknologi Malaysia for sponsoring first author to attend a 3-day publication workshop held in November 2014.

\section{REFERENCES}

Ali, U., Syed, J.H., Malik, R.N., Katsoyiannis, A., Li, J., Zhang, G. \& Jones, K.C. 2014. Organochlorine pesticides (OCPs) in South Asian region: A review. Science of the Total Environment 476-477: 705-717.

Cindoruk, S.S. 2011. Atmospheric organochlorine pesticide (OCP) levels in a metropolitan city in Turkey. Chemosphere 82(1): 78-87.

Coulibaly, L., Labib, M.E. \& Hazen, R. 2004. A GIS-based multimedia watershed model: Development and application. Chemosphere 55(7): 1067-1080.

Ene Antoaneta, B.O. \& Sion Alina. 2012. Levels and distribution of organochlorine pesticides (OCPs) and polycyclic aromatic hydrocarbons (PAHs) in topsoils from SE Romania. Science of The Total Environment 439: 76-86.

Jørgensen, S.E. 1994. Fundamentals of Ecological Modelling . 2nd ed. New York: Elsevier. p.57

Kim, K.S., Lee, Y.M., Lee, H.W., Jacobs Jr, D.R. \& Lee, D.H. 2015. Associations between organochlorine pesticides and cognition in U.S. elders: National Health and Nutrition Examination Survey. 1999-2002. Environment International 75(0): 87-92.

Kong, X.Z., Xu, F.L., He, W. \& Qin, N. 2014. Chapter 3 Development of Level-IV Fugacity-Based QWASI Model for Dynamic Multimedia Fate and Transport Processes of HCHs in Lake Chaohu, China. In Developments in Environmental Modelling. Vol. 26, edited by Jørgensen, S.E., Chang, N.B. \& Xu, F.L. New York: Elsevier. pp. 35 -73.

Liu, S., Lu, Y., Wang, T., Xie, S., Jones, K.C. \& Sweetman, A.J. 2014. Using gridded multimedia model to simulate spatial fate of Benzo[a]pyrene on regional scale. Environment International 63(0): 53-63.

Luo, Y., Gao, Q. \& Yang, X. 2007. Dynamic modeling of chemical fate and transport in multimedia environments at watershed scale-I: Theoretical considerations and model implementation. Journal of Environmental Management 83(1): 44-55.

Luzardo, O.P., Almeida-González, M., Henríquez-Hernández, L.A., Zumbado, M., Álvarez-León, E.E. \& Boada, L.D. 2012. Polychlorobiphenyls and organochlorine pesticides in conventional and organic brands of milk: Occurrence and dietary intake in the population of the Canary Islands (Spain). Chemosphere 88(3): 307-315.

MacKay, D. 2001. Multimedia Environmental Models: The Fugacity Approach. Boca Raton: CRC Press. p. 250.

Mackay, D., Shiu, W.Y., Ma, K.C. \& Lee, S.C. 2006. Handbook of Physical-Chemical Properties and Environmental Fate for Organic Chemicals. 2nd ed. Boca Raton: CRC Press.p. 1343.

Mahugija, J.A.M., Henkelmann, B. \& Schramm, K.W. 2014. Levels, compositions and distributions of organochlorine pesticide residues in soil 5-14 years after clean-up of former storage sites in Tanzania. Chemosphere 117: 330-337.
Sultana, J., Syed, J.H., Mahmood, A., Ali, U., Rehman, M.Y.A. Malik, R.N. \& Zhang, G. 2014. Investigation of organochlorine pesticides from the Indus Basin, Pakistan: Sources, air-soil exchange fluxes and risk assessment. Science of The Total Environment 497-498: 113-122.

Usman, A., Syed, J.H., NaseemMalik, R., Katsoyiannis, A., Li, J., Zhang, G. \& Jones, K.C. 2014. Organochlorine pesticides (OCPs) in South Asian region: A review. Science of the Total Environment 476-477: 705-717.

Wang, C., Feng, Y., Gao, P., Ren, N. \& Li, B.L. 2012. Simulation and prediction of phenolic compounds fate in Songhua River, China. Science of the Total Environment 431(0): 366-374.

Xiangzhen, K., He, W., Qin, N., Qishuang, H., Yang, B., Huiling, O. \& Fuliu, X. 2014. Modeling the multimedia fate dynamics of hexachlorocyclohexane in a large Chinese lake. Ecological Indicators 41: 65-74.

Xu, F.L., Qin, N., Zhu, Y., He, W., Kong, X.Z., Barbour, M.T. \& Tao, S. 2013. Multimedia fate modeling of polycyclic aromatic hydrocarbons (PAHs) in Lake Small Baiyangdian, Northern China. Ecological Modelling 252(0): 246-257.

Yu, Y., Li, Y., Shen, Z., Yang, Z., Mo, L., Kong, Y. \& Lou, I. 2014. Occurrence and possible sources of organochlorine pesticides (OCPs) and polychlorinated biphenyls (PCBs) along the Chao River, China. Chemosphere 114(0): 136-143.

Zhang, J., Xing, X., Qi, S., Tan, L., Yang, D., Chen, W., Yang, J. \& $\mathrm{Xu}, \mathrm{M} .2013$. Organochlorine pesticides (OCPs) in soils of the coastal areas along Sanduao Bay and Xinghua Bay, southeast China. Journal of Geochemical Exploration 125: 153-158.

Zhou, R., Zhu, L., Yang, K. \& Chen, Y. 2006. Distribution of organochlorine pesticides in surface water and sediments from Qiantang River, East China. Journal of Hazardous Materials 137(1): 68-75.

\section{Z.A. Ghani*}

Department of Environmental Engineering

Faculty of Civil Engineering

Universiti Teknologi Malaysia

81310 UTM, Johor Bahru, Johor Darul Takzim

Malaysia

\section{A.N. Anuar}

Department of Environment and Green Technology

Malaysia-Japan International Institute of Technology

Universiti Teknologi Malaysia

81310 UTM, Johor Bahru, Johor Darul Takzim

Malaysia

\section{Z.A. Majid}

Department of Chemistry

Faculty of Science

Universiti Teknologi Malaysia

81310 UTM, Johor Bahru, Johor Darul Takzim

Malaysia

\section{Yoneda}

Department of Environmental Engineering

Kyoto University

Japan

*Corresponding author; email: zairawatiabghani@yahoo.com

Received: 16 November 2015

Accepted: 14 May 2017 